\title{
'My tongue is the stylus of a skilled scribe' (Ps 45:2c): If so in the Scriptures, then why not also in translation?
}

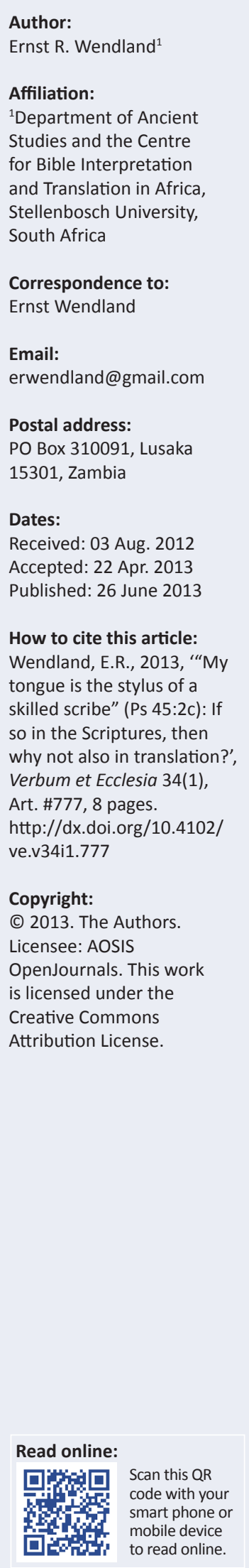

In this study, I survey seven characteristics of the poetic-rhetorical style of Psalm 45, with special reference to the 'sound effects' (phonological features) of the Hebrew text. This leads to a brief discussion of the translation of this psalm in Chewa, a Bantu language of southeastern Africa. How 'skilful' does this version sound in the vernacular, and why is this an

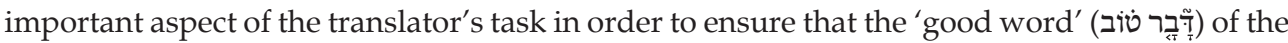
Bible is faithfully as well as forcefully transmitted? Suggestions will be offered to indicate how

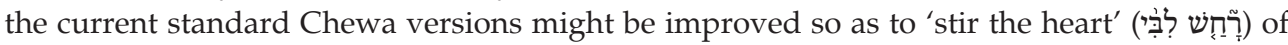
listeners also today. The results of the present study may be instructive and/or applicable in varying degrees to similar projects that aim to render the biblical text poetically, rhetorically and oratorically in the language of translation.

\section{Introduction}

Psalm 45 seems to be known more for its problematic text and extraordinary theme than for its theological insights. As Craigie (1983:337) observes, 'the text is difficult to translate and interpret at many points, and the analysis of the poetic structure is equally uncertain'. As for its subject matter, 'Psalm 45 is unique in the Psalter in that it is a royal marriage psalm' (Day 1992:93) and thus 'focuses on human beings rather than God' (Goldingay 2007:54; cf. McCann 1996:860), with the spotlight clearly fixed upon 'the king' (הַמְּל - vv. 2, 12, MT) (Mays 1994:180). However, 'God' (אֶ: (אלהים) is not entirely absent, being referred to explicitly twice (vv. 3, 8) and indeed, many commentators, beginning with the Targum (Whybray 1996:91), have seen an underlying 'secondary meaning' with reference to the divinely promised Messiah running as a covert theme throughout the psalm (Boice n.d.; Craigie 1983:340). The main thrust of my investigation is, however, not text-critical, exegetical or theological in nature (as important as such studies may be, cf. Nel 1998). Rather, it has a stylistic emphasis with special reference to the transmission of Psalm 45 in translation into a Bantu language, namely, Chewa. I shall focus therefore on the art and craft of the translators - the people with the 'skilful stylus' (or 'eloquent voice') today - and how they able to match something of the beauty of poetic expression as well as the power of the psalmist's persuasive (indeed, 'inspired' רחש-v. 2) rhetoric in a contemporary vernacular. Amongst the seven stylistic features identified for discussion, I shall pay particular attention to the psalm's phonic dimension because (1) this is so often neglected in translations, past and present and (2) it is such a vital aspect of the Hebrew text, whether in its original form or, correspondingly, during its subsequent transmission in another language.

\section{Seven rhetorical-poetic features of Psalm 45}

'Psalm 45 is rich in literary features' (Patterson 1985:30). By way of summary, I have selected seven stylistic devices for consideration: structural organisation, sonic effect, dynamic speech, figurative language, contextual reference, 'semantic density' and extensive intertextuality. I shall not be able to deal with any of these poetic qualities in detail but can simply point out their functional importance within the Hebrew text of Psalm 45, which implies that they must also be dealt with adequately in any translation (to be discussed in the next section). The attribute 'rhetorical' in the heading above calls attention to this vital functional dimension of biblical communication. Thus, the sacred text aims to 'persuade' with equivalent impact and appeal as in the original setting of religious use, whether for praising, appealing to, warning about, reinforcing or simply

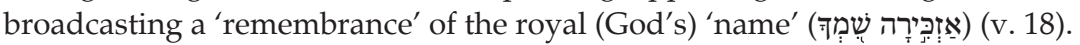

\section{Structural organisation}

Although this is not reflected in most (English) translations, the structure of Psalm 45 is rather straightforward and symmetrical in Hebrew. It may be summarised by the outline below (cf. Van Gemeren 1991:343). After each descriptive title, the applicable verses are given in parentheses, followed by the principal text 'markers' indicating the particular rhetorical-poetic devices that help to distinguish the onset ('aperture') of a new discourse unit or 'strophe' (cf. Wendland 
2002:118-119). The psalm's superscription is significant in relation to the text's overall theme (e.g. 'a love song' שִׁיר יְדידְת and has therefore been included in this overview of the compositional structure of Psalm 45:

A. Introduction (1-2): technical information, 1st person authorial (self) reference.

B. Appeal to the bridegroom (3-6): shift to 2 nd pers. sg. masc. pronouns.

C. Description of the bridegroom's glory (7-10): vocative opener + shift to non-imperatival verb forms.

$\mathrm{B}^{\prime}$ Appeal to the bride (11-13): vocative opener + shift to 2nd pers. sg. fem. pronominal references.

$C^{\prime}$ Description of the bride's glory (14-16): shift to 3rd pers. sg. fem. pronominal references.

$\mathrm{A}^{\prime}$ Conclusion (17-18): shift to 2 nd pers. sg. masc. pronominal references + concluding 1st person authorial (self) reference.

Thus, personal pronouns are instrumental in guiding the hearer or reader through this psalm's well-crafted organisation, that is, along with the subject matter at hand within a given discourse unit. Poetic symmetry, too, is manifest as the royal poet (one of 'the sons of Korah') presents a lyric summary of the wonderful wedding to which he was evidently a personal, privileged eye-witness. The psalm is divided into two major 'stanzas' - the second somewhat shorter than the first - with each one segmented further into two 'strophes' and developed around a pair of authorial addresses: the first to the king or groom, the second to his queen or bride. This balanced arrangement (having been made familiar through repeated liturgical performances) would also be helpful to any audience - that is, to assist them in following along or even participating in choral fashion, as the text was being chanted, recited or probably (given the occasion) sung to the accompaniment of selected musical instruments (cf. v. 9b).

\section{Sonic effect}

Sound is referred to at the very onset of Psalm 45 as the psalmist reveals that he 'is speaking (his panegyric) work

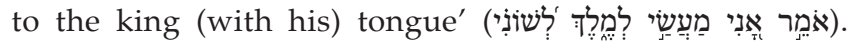
The prime subject of his lyric praise - the king - is also described as having 'lips [speech] anointed with grace'

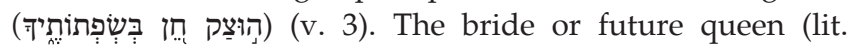
'daughter') is correspondingly exhorted at the onset of the psalm's second half to 'listen, and see (visualise?), and give

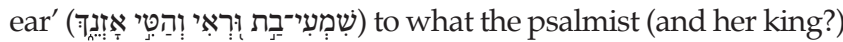
has to say to her (v. 11). Sound is also implied in the 'stringed instruments' (Craigie 1983:337) of verse 9, the corresponding voices of 'gladness' (שמח) emanating from the bridal procession (v. 16) and the psalmist's vow to 'perpetuate the

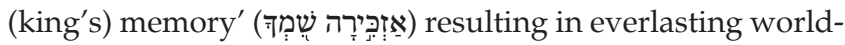

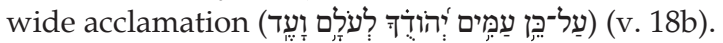

The preceding colon exhibits some of the sonorous, rhythmic alliteration that is heard periodically throughout this psalm; cf. also verse $8 b-c$ (note the liquid and sillibant sounds):

\begin{tabular}{|c|c|}
\hline 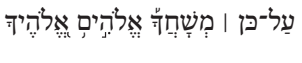 & Therefore God, your God, has \\
\hline 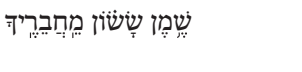 & $\begin{array}{l}\text { (with) the oil of joy more than your } \\
\text { companions. }\end{array}$ \\
\hline
\end{tabular}

The predominant phonological feature and identifying characteristic of Hebrew poetry is of course the device of lineal parallelism in the form of strophic sets (see above) of bi- or tricola. Bratcher and Reyburn (1991:420) assert that 'this psalm has a minimum of semantic parallelism', but this view would have to be understood in a very narrow sense as referring to synonymous parallelism. In fact, Psalm 45, like any other, is constituted completely by parallel lineation, here primarily of the additive type, including five tricola (vv. 2, 3, 8, 12, 15; Craigie 1983:335-336) and with a prevalent accentual rhythm of 4+4 (Goldingay 2007:55). These prominent 'sound effects', featuring an extended, balanced, cadenced style of composition, literally calls out for public oral articulation as indeed the psalmist himself attests at this song-poem's very beginning.

\section{Dynamic speech}

As already noted, Psalm 45 psalm was, like virtually all ancient formal and informal discourse, composed and transmitted orally (cf. Craigie 1983:339; Hilber 2009:357) - in the case of the Psalter also explicitly in the form of direct speech. God, or the Lord (Yahweh), was normally the addressee whilst the psalmist and/or the people of God were the usual speaker(s). Such composition thus lends itself well to a functional ('speech-act') analysis: What were the speakers doing through their words? What pragmatic goals were they seeking to accomplish? In general, are the varied cola (poetic utterances) of a given psalm informative, expressive, directive, evocative, eulogistic, relational, performative and/or artistic in nature? More specifically then, what communicative intention does a particular colon (bicolon) embody or express, and what is the expected outcome or impact upon the audience or addressee(s)? In short, "the three [speech] acts are "of saying" (locution), "in saying" (illocution) and "by saying" (perlocution)' (Briggs 2008:88, original italics).

What can speech-act (SA) analysis tell us about Psalm 45? First of all, we note that related sets of SAs tend to group themselves according to the stanzaic and strophic structure of the text that was outlined above (for two classificatory systems, see Wendland 2011:44, 46; cf. Levine 1995:95). Thus, the psalm leads off with several combined SAs of expressive exaltation and self-affirmation (v. 2). The first strophe of stanza one then consists of a sequence of SAs that generally praise and exhort the king or groom in terms of his royal character: commendation, encouragement and especially an appeal to valour in the face of Israel's enemies (vv. 3-6). This leads to the second strophe (vv. 7-10), which begins by describing the king with regard to his governance but then subtly shifts to a portrayal of the physical setting of his wedding. Stanza two offers fatherly counsel, advice and encouragement to the future bride (1st strophe, vv. 11-13), followed by a more physical description of her person and joyous surroundings (2nd strophe, vv. 14-16). The psalmist interjects again at the end of the song (vv. 17-18) with a benediction cum prediction concerning future progeny, coupled with a vow to perpetuate the king's glorious memory through his poetry. Here we 
have then an instance of what Patterson (1985:31) calls 'a rhetorical parallelism that fits the stated needs of lyricism for progression' - a poem with a particular purpose in mind.

In any such classificatory scheme, there is of course a considerable amount of interlocking and overlapping, as one SA meshes with or is moulded into another. This becomes a challenge for translators as they seek to convey the same or similar pragmatic implications in their language. Especially difficult are those cases of convergence where a single utterance (colon or bicolon) appears to express two or more SAs at once but on different levels of interpretation. For example, a strong case can be made that the apparent descriptive praise of the divinely appointed king in verses $6-7$ is simultaneously also an implicit exhortation for him to continue to reflect the attributes of 'truth' and 'justice' (perhaps 'humility' עַנְוֹה as well, cf. verse 4; Craigie 1983:336; Perowne 1878:376) throughout his current rule and for the sake of his future reputation (v. 18b).

\section{Figurative language}

In terms of its genre, or literary type, Psalm 45 may be classified as a 'royal psalm' (Craigie 1983:337; Wendland 2002:51) that functions more specifically as an 'epithamalium' - a wedding song - and, especially if a public choral arrangement were involved, also as an 'encomium' - a song of communal praise (Preminger \& Brogan 1993:332, 378; Ryken 1992:273, 293). The elaborate, albeit rather cryptic (to

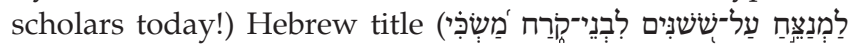
[For the music director, to the melody of Lilies, by the Sons of Korah, a maskil, a wedding song] seems to refer to a musical composition of some sort (Craigie 1983:264, 336), which would certainly be suitable for 'a love song' (שיָיר יְדידְת). In any case, such a lovely lyric piece features a diversity of figurative language (especially metaphor) and related imagery that pertains to the personage(s) being praised. This song-poem thus 'ties together in a single bunch of many colored flowers a variety of essential motifs and thoughts associated with the [wedding] feast' (Goldingay 2007:55) as well as the various ceremonies that accompanied the several stages of a Jewish traditional marriage celebration.

Ryken, Wilhoit and Longman III (1998) set the scene well in what amounts to a semi-narrative description of the joyous communal, dual processional event, a scenario that abounds in 'extravagant joy and sensory richness':

The poet sets the tone at the outset when he asserts, 'My heart overflows with a goodly theme' (Ps 45:1, RSV). The couple stand at the center of the event, and both appear at their best. The king is 'fairest of the sons of men' (Ps 45:2, RSV), girded with his sword in 'glory and majesty' (Ps 45:3). He is anointed with 'the oil of gladness', and his robes 'are all fragrant with myrrh and aloes and cassia' (Ps 45:7-8, RSV). The princess, for her part, 'is decked in her chamber with gold-woven robes' (Ps 45:13) and then led to the king 'in many robes ... with her virgin companions' (Ps 45:14, RSV). The whole procession enters the palace of the king 'with joy and gladness' (Ps 45:15, RSV). (p. 938)

Although two persons are naturally involved in this wedding scene, the focus is undoubtedly centred upon the regal groom, even when his bride is being described (e.g. vv. 12, 14-15). Furthermore, this psalm includes not only rich wedding imagery but also incorporates, as befits a royal personage, figurative references to his outstanding speaking (v. 3b), fighting (vv. 4-6) and ruling capabilities (vv. 7-8a). It is important to note that the 'imagery' of this psalm is patently visual in nature, but it further appeals to the sense of smell (e.g. 'myrrh and aloes and cassia', v. 9a) and sound as well (e.g. 'strings', v. 9b).

\section{Contextual reference}

Some commentators take space to speculate about the original life-setting of Psalm 45 and who might have been the king and bride concerned, for example: Solomon and the daughter of either Pharaoh, Hiram or the king of Tyre; Ahab and Jezebel (which would be most ironic in view of the psalm's later typological hermeneutical history, but see Holliday 1996:28; Terrien 2003:367-368); Joram, son of Jehoshaphat, and Athaliah (also ironic); or most far-fetched, some later Persian king and his wife (or one of them) (Perowne 1878:367). Truth be told, we cannot know for sure, and 'all that can be safely said is that [this psalm] originated during the existence of the [Jewish] monarchy and was probably used [officially] at several royal weddings' (McCann 1996:861, words in brackets added; cf. Day 1992:93). However, it is likely that Psalm 45 was also used 'unofficially', that is, liturgically for Temple worship, especially in later years to celebrate the covenantal relationship between Yahweh and his chosen people.

As our survey of the psalm's figurative language above would suggest, the extra-linguistic setting of the text is a crucial factor in its contemporary interpretation. Thus, an understanding of the Ancient Near Eastern (ANE) contextual background can lend some vital insight into the text. For example, the customs referred to in verses 8 and 9 (anointing, wearing perfumed robes, festive stringed music, etc.) could be applied to a wedding ceremony or the coronation of a king, two public events that were often combined (Walton, Matthews \& Chavalas 2000:528). Another important perspective affects the interpretation and hence also the translation of verse 13. 'A daughter of Tyre' (בת־ץ) most likely does not refer to a particular person - some prominent woman (perhaps even the queen herself) from the Phoenician seaport city of Tyre - but metonymically to the wealthy merchant inhabitants of that location, who 'was associated with the epitome of wealth (Ezk 27:1-33)' (Hilber 2009:359; cf. Walton et al. 2000:529).

The psalm's prevailing point of reference involving ANE wedding customs and associated circumstances is also helpful for understanding the structure as well as the message of Psalm 45. As suggested earlier, Psalm 45 consists of a narrator frame that opens (v. 1) and closes (vv. 17-18) the text as a whole. In between, we have two principal poetic units ('stanzas') that present a quasi-narrative discourse featuring two central characters, first the groom and then the bride. These two stanzas correspond to the two essential journeys connected with a typical Jewish wedding celebration: The groom must first travel with his company to the bride's 
home (vv. 3-10), and then with the addition of her entourage, they all move in the opposite direction back to the groom's home (vv. 11-16). In the first stanza, we hear effusive praise extolling the virtues of the groom - how fitting a person he is (or must be) in terms of performance and character. The second stanza features a contrast in both content and tone as the bride-to-be is paternally (or maternally), as it were, advised to adopt a completely new outlook on life (v. 11) - in submission to her husband, yes (v. 12), but also in the prospect of an optimistic future (v. 16) that promises both respect (v. 13) and great familial responsibility (implied in v. 17).

\section{'Semantic density'}

The term 'semantic density' applies to words or phrases that arguably have more than one compatible sense in a given co-textual setting (Wendland 1990:302-304). The qualifier 'arguably' is necessary because commentators may disagree on whether or not this literary device is actually present in the biblical text and whether deliberate authorial intention can be demonstrated in such usage as distinct from its being a product of the history of Scripture interpretation and/or contemporary scholarly consensus. Such functional semantic ambiguity is a typical characteristic of most, if not all, poetic traditions, and it certainly plays a central role in the poetic books of the Hebrew Bible, especially in texts that are more lyric and panegyric in nature such as the Canticles and Psalm 45.

Along with the abundance of figurative language, already noted, hyperbolic exaggeration appears to be an important feature of this psalm. This is the case when a human personage, even some great royal figure (or dynasty), is being designated by, for example, references like 'God has blessed you forever'

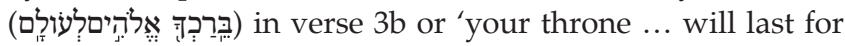

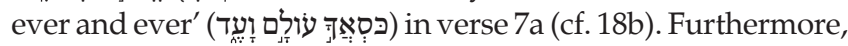
the king is described at times with 'characteristics normally reserved for God, namely, "splendour" and "majesty" (v. 4; cf. Ps 96:6)' (Craigie 1983:339; cf. also vv. 5-6). In the wider context of Scripture (see 'intertextuality' below), commentators early on began to construe the language of these texts as exceeding 'poetic license' and thus having divine or messianic typological significance (Hilber 2009:378; Mays 1994:182; Whybray 1996:91).

Another poetic-rhetorical feature of Psalm 45 that supports a broader interpretive perspective is its use of the term 'God' (אלקלהים) to refer figuratively to the king but within a wider hermeneutical framework also to its literal divine referent (v. 7a). Such semantically 'dense' nominal usage is coupled with the associated second person (m.) singular pronoun 'you or your' in referential co-texts where, humanly speaking and hyperbole aside, it does not quite belong, for example: 'the nations [i.e. the whole wide world!] will praise you forever

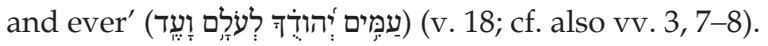

\section{Extensive intertextuality}

As suggested above, the surrounding co-textual setting of the Psalter itself serves to shape our understanding of Psalm 45 with regard to its literal as well as any deeper theological significance. The various psalms, though probably composed individually, were never meant to be read silently and interpreted in isolation. Rather, they were gathered into 'books' and finally the Psalms-scroll as a whole so that they might be sung, recited, chanted or otherwise articulated. This could take place in personal (audible!) reflective meditation and prayer or during public worship and communal liturgical expression with the memory of the entire psalmic corpus acting as a conceptual point of reference and a hermeneutical guide. This process is well illustrated in the book of Hebrews with special reference to the book of Psalms and, in particular, the psalm under consideration: Psalm 45:7-8 $>$ Hebrews 1:8-9 (with an emphasis on the text's orality in Heb $1: 6 ; 2: 12 ; 3: 7$, etc.).

The most immediate co-textual grouping for Psalm 45 is that 'of or for or by the sons of Korah' (לְבְני־-קָרַח), a distinct corpus that is divided in two within books II (Ps 42-49) and III (Ps 84-88). Psalm 45 is most closely related thematically to the Korahite psalms that immediately follow it as Firth (2008) claims (cf. Patterson 1985:32):

The psalm insists on the close relationship between God and his king and prepares the way for the great affirmations about the reign of God that we find in Psalms 46 - 48. (p. 27)

There are a number of other psalms with an explicit reference to the king (or King). These are the so-called 'royal psalms', which according to Gunkel include at least the following: 'Psalms 2; 18; 20; 21; 45; 72; 89; 101; 110; 132; 144:1-11' (Tucker 2008:584; cf. Futato 2008:181). The notion of Yahweh's kingship may be regarded as the 'root metaphor' of the entire Psalter: 'All subsequent affirmations about the work and activity of Yahweh are predicated upon the assumption that Yahweh reigns as king' (Tucker 2008:591). 'The psalms are the poetry of the reign of the LORD' (Mays 1994:30). Such a prevailing intertextual resonance involving this preeminent theme of divine royalty was (and is) bound to affect the understanding of Psalm 45 as it was transmitted both orally and in writing over the ages, despite the fact that this transmission was undoubtedly not within the conceptual frame of reference of its original composer. There is thus a marriage of hermeneutical horizons in this distinctive wedding hymn, and we see (hear) and mentally merge many thematic parallels like the following:

The poet proclaims of his earthly master [the king], 'I commemorate your fame of all generations,/so people will praise you forever and ever' (Ps. 45:18), just as the psalmist praises God, his heavenly lord and master: 'Every day will I bless You/and praise Your name forever and ever' (145:2). (Levine 1995:93-94)

In an interesting reversal of the anthropopathic theme of 'divine suffering in the Psalter' as documented by Gericke (2012), we have here in Psalm 45 (amongst others) a glimpse of manifold 'divine rejoicing'. Such happiness has been evoked, as it were, by the acclamation, honour, devotion and testimony of God's people $(45: 9,11,12,18)$ - a mixed multitude embracing members of every epoch, nation, culture and language ( $\operatorname{Rv} 7: 9-10)$. To be sure, this is certainly a 'noble theme' concerning a most praiseworthy personage, 
which therefore requires the expert 'tongue' and 'pen' of a 'skilled' orator and translator in order to 'perpetuate [his] memory through all generations' (Ps 45:2, 18, NIV).

\section{A blunt 'stylus' and a dull sound in translation?}

Why pay so much attention to the poetic-rhetorical forms of the original text? Can translators not simply (more quickly and efficiently) access the text via its translation in some language of wider communication (e.g. English, French, Afrikaans) and work from there? That of course is the 'easy way out', and many translation teams operate in such a way in order to cut costs and the time needed to complete their work. Such a policy does, however, not demonstrate what Nord terms sufficient 'loyalty' to (1997:125) - and, we might add, also respect for - the original author-composer of the source text, especially in the case of a sacred, 'high value' corpus such as the Hebrew Scriptures.

First of all then, translators must convince themselves of this fact, namely the excellent literary, indeed 'oratorical', quality of the original (Wendland 2004:272-276). The only way to do this is by means of a careful linguistic and literary analysis of the source document in order to reveal the diverse artistic, aural and rhetorical properties of the text which complement its semantic content. Such comprehensive study will both motivate and encourage them to seek to reproduce a corresponding version in their mother tongue (all other conditions such as project funding and support, translator competence and experience, target audience desire and expectations being equal).

What confronts us when we read most versions in the major languages today? Generally speaking, most discerning English-speaking respondents are not very impressed by the literary (let alone oratorical) properties of the many Bible translations that are available. Even more 'literary' renditions often fall far short of the mark of excellence set by the original. The Revised English Bible, verse 2, with several possibly problematic points underlined (i.e. with respect to lexical or grammatical usage and stylistic fluency) could serve as a case in point:

MY heart is astir with a noble theme;

in honour of a king I recite the song I have composed,

and my tongue runs swiftly like the pen of an expert scribe.

Contemporary readers and especially hearers of the text of Scripture must certainly wonder (if they take the time to reflect about it): Just where is that 'skilful tongue' that the psalmist lauds here? The translation that they are currently reading (or hearing) certainly does not sound so sweet, at least not in their language. The same sort of reaction is all too common in vernaculars all over the world today - if people are honest enough to admit it. For example, here is how verse 2 sounds in back-translation from the old (1922), but still very popular, Chewa (Nyanja) Protestant 'missionary' version (formatted below as published):

\author{
My heart overflows with a love- \\ ly thing: \\ I say (am referring to) what I have composed of/about a chief/king: \\ My tongue is a 'pen' that is qui- \\ ck to write.
}

That rendition is neither 'lovely' in terms of Chewa stylistic poetic form nor intelligible with regard to what is meant. The translators were apparently too 'quick to write' down what they thought the text should say in the vernacular.

In this section, I shall just briefly (due to space restrictions) propose a number of ways in which a contemporary Chewa translation might be fashioned in order to express a closer literary (oratorical) 'functional equivalent' of Psalm 45 (Wendland 2004:12-14). My suggestions will relate to the topics of the 'seven rhetorical-poetic features' of the Hebrew text that were outlined above, with special emphasis on those that involve the sound dimension of discourse.

\section{Structural organisation}

The text of the old Chewa translation (Buku Lopatulika 'Book Set-apart') is not subdivided into paragraph units at all; it consists of an intimidating single block-mass of verses. It is necessary, therefore, to assist readers - and through them hearers as well - to format the text in a way that gives them certain clues concerning the structural organisation of the original. In the case of Psalm 45, this would include the major divisions into an introduction (vv. 1-2), two principal stanzas (3-10, 11-16) and a conclusion (17-18). It is helpful to insert the minor strophic (poetic paragraph) units as well since they reflect some important distinctions with regard to topic, tone, mood, implication and so forth.

For certain, more sophisticated, readers, the format and typography of the text may be modified or enhanced further in order to display significant parallels (whether correspondences or contrasts) and high (peak) points. Indentation (to varying degrees) might be employed, for example, to distinguish this psalm's author-oriented introduction and conclusion whilst the use of different typefaces can draw attention to critical utterances in the discourse - boldface print, for example, to highlight the pair of passages that bring 'God' into a description of the character of the 'king' (and, significantly, are later cited in Heb 1:8-9). Most modern versions also feature brief headings, or titles, to indicate a psalm's overall theme and sub-points, in Chewa, for example: 'A song for the king/chief's wedding' (Nyimbo ya pa ukwati wa mfumu), followed by 'Words concerning the king' (Mau okhudza mfumu, vv. 3-10), 'Words concerning the queen' (Mau okhudza mfumukazi, vv. 11-16) and 'Concluding words' (Mau omaliza, vv. 17-18).

\section{Sonic effect}

A few general features involve the poetic phonology in conjunction with the text format referred to above. Thus, in the case of Hebrew poetry, it is important to reflect the parallel lines as clearly as possible. This normally requires a single column of unjustified print on the page - not the 
normal, double blocks of justified text that characterise most (English) Bibles today. The latter format frequently results in lines that are broken in awkward (non-meaningful) places along with excessive hyphenation (as illustrated by the Chewa sample given earlier). These are purely formal, typographical principles that can be applied no matter what the style of translation happens to be, whether literal or idiomatic.

The 'sound effects' of a given version may be either augmented (to correspond with the Hebrew text) or diminished, depending on the type of translation. Thus, it demands a special effort - and poetic expertise! - to render the Psalms in a manner that does justice to their original sonic significance, that is, with rhythmic, euphonious utterances that have aural impact and aesthetic appeal. In particular, translators would want to stylistically mark those passages that are distinguished somehow in the Hebrew source text, whether in terms of poetic form, thematic content and/or rhetorical function. Verse two of Psalm 45 is an obvious candidate for such attention, as already noted. The old Chewa version, reproduced in back-translation above, certainly leaves much to be desired. The following is a revised (poetically 'sharpened') rendition of a more recent 'popular-language' version (Buku Loyera 'Holy Book'). In this case, the actual vernacular text is recorded for reference:

Wadzazatu mtima wanga ndi nkhani yokomadi.

It's filled to the brim my heart with this lovely theme.

Nditi ndimbire mfumu yathu nyimbo yangayi.

I propose to sing for our king/chief this song of mine.

Lilime langali liri thwa! lofunitsa kulankhula,

My own tongue is very-sharp! so eager to speak,

Lifanafana ndi katswiri wodziwa kulembadi!

It resembles an expert who really knows how to write!

The phonological qualities of this poetically-enhanced version should be audible, at least in part, even to those who do not speak Chewa.

\section{Dynamic speech}

The first step in dealing with the 'dynamic speech' of the biblical text in translation is to search for a functionallyequivalent, oral-aural genre of discourse in the 'target language'. In Africa, this is usually not a problem because most cultures of this continent can boast an ancient and still vibrant tradition of oral art forms, including folk narratives, histories, myths, legends, riddles, proverbs, songs and various kinds of poetry, including royal 'praise verse'. Often these traditional oral genres extend their life, albeit in a somewhat modified form, in the extensive written literatures that have developed during both the colonial age and in post-independence years. Amongst the Chewa people, for example, a multifaceted, oral and written genre of lyric poetry (ndakatulo) is available for use when translating various types of biblical 'poetic' discourse, including the Psalter. Ndakatulo lyrics feature rhythmic lineation, vivid imagery (including emphatic evocative predications or 'ideophones'), syntactic transposition (for focus and emphasis), phonesthetic appeal (alliteration, punning, rhyme, etc.), deictic specification, formal and semantic condensation or expansion, lexical intensification, rhetorical questions and synonymous reiteration (Wendland 2004:330-336).
A sample of ndakatulo poetry was given above (Ps 45:2). Another instance is the following rendition of this psalm's final, climactic verse (18):

\section{Mbiri yanuyo ndidzaibukitsa ku mibadwo yonse.}

This reputation of yours I'll broadcast it to all generations.

Motero anthu akukumbukireni, a mitundu yonse -

In this way people should remember you, those of all nations adzatamande dzina lanu lokomali kwa muyayaya!

They will praise your pleasant name (or character) for-everand-ever!

At the very minimum, it would seem appropriate to employ such a manifestly poetic style (assuming functional equivalence also in terms of illocutionary force) for the key verses of a given psalm (or any corresponding biblical pericope). This would normally include passages that mark major structural boundaries within the text (aperture or closure), those serving to signal a peak point with regard to the psalm's principal theme(s) or theological content and those that express the psalmist's deepest feelings and attitudes, whether positive or negative in tone.

\section{Figurative language}

The root metaphor of the 'king' (chief) and associated imagery, as surveyed above, would be familiar in many regions of Africa, though some ethnic groups (e.g. the Tonga of southern Zambia) do not have a strong royal tradition. In the second strophe of the first stanza, the images shift to those connected with the wedding of some wealthy person, and these too would not be very difficult to convey in a meaningorientated translation.

The main issue that translators must confront is the degree to which they will use local cultural equivalents for the specific items found in the biblical text. In many cases, the correspondence is rather close, for example 'long knife' (lupanga) for a 'sword' (חֶרב) in verse 4; the 'chief's stick' (ndodo yachifumu) for 'sceptre' (שָקברט) in verse 7 or '[castor-bean] oil' (mafuta ansatsi) for the '[olive] oil' (שֶֶׁ) of ceremonial anointing in verse 8 . In other cases, however, either transliterations or indigenous correspondents must be employed. This decision becomes especially important in verse 9, for example, where the imagery also involves olfactory stimulation in the specific aromatic oils that are mentioned, 'myrrh and aloes and cassia'

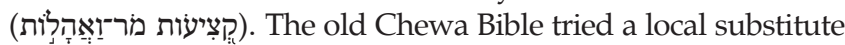
for 'aloes'. Unfortunately, it was the wrong choice, for khonje is a homonymic term that refers either to a 'sisal plant' or a 'bunch of bananas'! The new Chewa version made use of three transliterations (mure, aloe ndi kasiya), which would be unknown to most listeners, but at least, the text has marked the overall sense impression intended by preceding the foreign terms with the generic qualifier zonunkhira 'sweetsmelling things'.

\section{Contextual reference}

In the case of the final three aspects of the poetic-rhetorical dimension of biblical discourse (in the Psalms and elsewhere), we move from a focus on the translated text to its accompanying paratext and the challenge of constructing 
a cognitive 'frame of reference' sufficient to guide and enrich the text's interpretation (cf. Wilt \& Wendland 2008:23-101). As noted above, there are a number of concepts and customs, either stated explicitly in Psalm 45 or implied, which are alien or unfamiliar to the Chewa people living in SE Africa today. A few of these notions would be completely foreign and hence unknown, such as the transferred reference (via the king) to God as a militaristic 'divine warrior' (vv. 4-6; cf. Ps 18:14; 77:17; Hilber 2009:358) or the application of the title 'God' to earthly rulers (v. 7; cf. Ps 82:6; Ex 22:6) or the psalmist's instruction to the bride to 'forget your people and your father's house' (v. 11; the Chewa are traditionally matrilineal and matrilocal). Other concepts, though initially not understood, might be more readily clarified, for example, the king's 'riding' in a victory celebration (v. 5), the festive wearing of perfumed robes (v. 9), gold that originates in 'Ophir' (v. 10) or the significance of the city of 'Tyre' (v. 13, which has nothing to do with today's vehicle 'tyres'!).

In all of these cases of potential ambiguity or obscurity, the necessary conceptual background for understanding the text can normally be provided, at least in part, through explanatory and descriptive footnotes, supplemented when and where possible by an occasional illustration or photograph. The process of effective footnoting cannot be taken for granted, however, and often requires just as much scholarly, attention coupled with community testing as the translation itself (Wendland 2004:370-379). Furthermore, just as in the case of the translation, these auxiliary materials need to be composed with an 'ear' to how they will sound when read out loud. Such an audio-oriented procedure will help to ensure that the text does not become too complicated for the intended audience to mentally 'process', and it may also serve as the basis for an actual oral rendition of the translation (via CD, MP3, radio, etc.), that is, the vernacular version supplemented in some discrete way by oralised paratextual helps (e.g. through vocally distinct 'asides').

\section{'Semantic density'}

To a certain degree, this poetic feature overlaps with the preceding one (contextual reference) in terms of the way it may be handled in a modern translation. Thus, a number of possible points of 'semantic density' were pointed out in Psalm 45 in the earlier discussion of this topic, virtually all of them having to do with some potential divine implication, whether in reference to God and Israel or to the Messiah and the NT people of God. Since this has been such a prominent aspect of this psalm in the history of the text's interpretation, it is only fair that readers and hearers today, in whatever language, are made a part of the on-going hermeneutical conversation leading to locally contextualised theological understandings and contemporary moral-ethical applications.

Most 'ordinary' lay listeners, however, will not discern this interpretive option in the vernacular texts available to them, whether the older or more recent versions. For this reason, an annotated 'study Bible' is being prepared by the Bible Society of Malawi in order to serve this purpose - firstly in written form but also keeping in mind the ear of a future audience. Perhaps the greatest need in Psalm 45 is for the three references to 'God' to be clarified in verses 7-8, first of all, in terms of the overt meaning of the text as it reads (is heard) and then also with reference to a possible 'second meaning' (as C.S. Lewis has termed it; Craigie 1983:340; Van Gemeren 1991:45). Such additional theological significance cannot justifiably be incorporated within the translation or even asserted in a note as being actually intended by the original court poet but only as a sense that has accumulated for this psalm by virtue of thematic 'attraction' from related passages in the Psalter (e.g. Ps 89:26-29) and other books of the Hebrew Scriptures (e.g. 2 Sm 7:14-16; 23:5; Is 9:6; 11:4-5).

\section{Extensive intertextuality}

The preceding discussion raises once again the importance of careful cross-referencing as a supplementary device to aid in the interpretation of any contemporary translation. The aim is to suggest how one text relates to, or depends upon, another for its ultimate canonical understanding, both within a given pericope like Psalm 45 and within sacred corpus of Scripture as a whole, Hebrews 1:8-9 for example, as developed from Psalm 45:7-8. However, especially prominent correspondences like the preceding will probably require fuller explanation in a footnote. A 'careful', selective or discriminating referencing procedure is needed so that the paratext is not overburdened with passages, many of which have only a tenuous semantic relationship with the text at hand, for example, the topic of 'blessing' (v. 3), 'the nations' (v. 5) or 'anointing' (v. 7). Too many minimal 'clues' and referential 'red herrings' will only result in an overly diffuse, perhaps even misleading interpretation or may simply discourage readers from using the cross-reference system at all.

Again the issue of implementing such intertextual orientation in a non-print, audio version of the Scriptures may be considered. A number of potential solutions are available that provide various options regarding how to incorporate such important verbal resonances aurally in a manner that is not disruptive or distracting in relation to a particular verse of the translation. In fact, the feature of allusion may even be easier to include in a purely vocal version due to the availability of many flexible features of sound - from different voices, to the use of music or other acoustic signals (e.g. a gong, chime, drum beat). In a full-media, audio-visual presentation, of course, many additional techniques are accessible for revealing the vital intertextual character of the current biblical text.

\section{Conclusion}

'In Psalm 45, the poet likens the composition and oral performance of this song (his "tongue") to the "pen" of a skilful scribe, a song of beauty befitting the occasion of the king's wedding' (Hilber 2009:357). The preceding reference thus construes this lyric piece more or less on its literal 'face' (or 'ear'!) value in relation to its original extralinguistic setting in the Ancient Near East. As many subsequent commentators 
have observed, 'in the postmonarchical period this "good saying" for a king's wedding was read by some as a messianic text,' whilst 'others likely found in it an allegory of the relation between God and the people of God' (Mays 1994:181-182; cf. Hs 1-3; Jr 2; Ezk 16; Is 62:1-5). By the time the NT was written (e.g. Heb 1:8-9), it is clear that the divine-human allegorical reference has been narrowed through intertextual reflection to embrace the relationship between Christ and his Church (Craigie 1983:341; cf. Whybray 1996:91-92). The text thus develops a 'typological significance' (Van Gemeren 1991:343) regarding the Messiah's royal sovereignty and also his loving 'truth, humility, and righteousness' (v. 4, NIV). Even in the realm of purely human interpersonal relationships, Psalm 45 held great import for the people of Israel: 'Not only the king's prosperity and wellbeing, but his character and spiritual privileges as well were to be shared by all the community of believers' (Patterson 1985:46).

The long history of Jewish and Christian interpretation then has plainly answered the 'crucial question': 'Why was this seemingly secular psalm included in the book of Psalms?' (McCann 1996:861; cf. Terrien 2003:367). Therefore, it also behoves Bible translators to give Psalm 45 the keen attention it deserves and hence to render the text not only poetically in terms of an artistic style and rhetorically with regard to its prominent pragmatic implications but also oratorically in view of how the psalm is primarily intended to be transmitted. The first two verses in fact set forth a rather formidable challenge to all translators - and their project associates (Wendland 2004:369-379): How can we render this text in a manner that confirms and conforms to what it claims for itself in the very beginning? Will our version actually 'stir the hearts' of those who hear it? Such a pericope is definitely meant to be publicly declaimed as would have been the case in the original event and on behalf of the king (King) himself (v. 3)

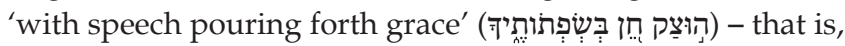
by means of beautiful sound to complement the bountifully beneficent sense of the text!

\section{Acknowledgements}

I wish to acknowledge the helpful advice and assistance of several anonymous reviewers and the copy editor in producing this final published version.

\section{Competing interests}

The author declares that he has no financial or personal relationship(s) that may have inappropriately influenced him in writing this article.

\section{References}

Boice, J., n.d., Studies in Psalms, vol. 2 (42-106), Alliance (audio tape series), Philadelphia, PA.

Bratcher, R.G. \& Reyburn, W.D., 1991, A translator's handbook on the book of Psalms, United Bible Societies, New York, NY.

Briggs, R.S., 2008, 'Speech-act theory', in D.G. Firth \& J.A. Grant (eds.), Words \& the Word: Explorations in Biblical interpretation \& literary theory, pp. 75-110, IVP Academic, Downers Grove, ILL.

Craigie, P.C., 1983, Psalms 1-50 (Word Biblical Commentary, vol. 19), Word Books, Waco, TX.

Day, J., 1992, Psalms (Old Testament Guides), JSOT Press, Sheffield, UK.

Firth, D.G., 2008, 'Asaph and sons of Korah', in T. Longman III \& P. Enns (eds.), Dictionary of the Old Testament: Wisdom, poetry \& writings, pp. 24-27, IVP Academic, Downers Grove, IL.

Futato, M.D., 2008, Interpreting the Psalms: An exegetical handbook, Kregel, Grand Rapids.

Gericke, J.W., 2012, 'What is it like to be a god? A philosophical clarification of instances of divine suffering in the Psalter', Verbum et Ecclesia 33(1), Art. \#700, 6 pages. $\mathrm{http}: / / \mathrm{dx}$.doi.org/10.4102/ve.v33i1.700

Goldingay, J., 2007, Psalms, vol. 2: Psalms 42-89 (BCOT), Baker Academic, Grand Rapids, MI.

Hilber, J.H., 2009, 'Psalms', in J.H. Walton (ed.), Zondervan illustrated Bible backgrounds commentary, pp. 316-463, Zondervan, Grand Rapids, MI.

Holliday, W.L., 1996, The Psalms through three thousand years: Prayerbook of a cloud of witnesses, Fortress Press, Minneapolis, MN.

Levine, H.J., 1995, Sing unto God a new song: A contemporary reading of the Psalms, Indiana University Press, Bloomington, IN.

Lewis, C.S., 1958, Reflections on the Psalms, Geoffrey Bles, London.

Mays, J.L., 1994, Psalms (Interpretation), John Knox Press, Louisville, KY.

McCann, J.C., 1996, 'Psalms', in L.E. Keck (ed.), The new interpreter's Bible, vol. IV, pp. 641-1280, Abingdon Press, Nashville, TN.

Nel, P.J., 1998, 'The theology of the royal psalms', Old Testament Essays 11(1), 71-92.

Nord, C., 1997, Translating as a purposeful activity: Functionalist approaches explained, St. Jerome, Manchester, UK.

Patterson, R.D., 1985, 'A multiplex approach to Psalm 45', Grace Theological Journal 6(1), 29-48.

Perowne, J.J.S., 1878, The book of Psalms, George Bell \& Sons, London, UK.

Preminger, A. \& Brogan, T.V.F., 1993, The new Princeton encyclopedia of poetry and poetics, Princeton University Press, Princeton, NJ.

Ryken, L., 1992, Words of delight: A literary introduction to the Bible, Baker Books, Grand Rapids, MI.

Ryken, L., Wilhoit, J.C. \& Longman III, T., 1998, Dictionary of Biblical imagery, InterVarsity Press, Downers Grove, ILL. PMid:17154441

Terrien, S., 2003, The Psalms: Strophic structure and theological commentary, Eerdmans, Grand Rapids, MI.

Tucker, Jnr., W.D., 2008, 'Psalms 1: Book of', in T. Longman III \& P. Enns (eds.), Dictionary of the Old Testament: Wisdom, poetry \& writings, pp. 578-593, IVP Academic, Downers Grove, IL.

Van Gemeren, W.A., 1991, 'Psalms', in F.E. Gaebelein (ed.), The expositor's Bible commentary, vol. 5, pp. 1-880, Zondervan, Grand Rapids, MI.

Walton, J.H., Matthews, V.H. \& Chavalas, M.W., 2000, The IVP Bible background commentary: Old Testament, InterVarsity, Downers Grove, ILL.

Wendland, E.R., 1990, "'What is truth?" Semantic density and the language of the Johannine epistles', Neotestamentica 24(2), 301-333.

Wendland, E.R., 2002, Analyzing the Psalms, 2nd edn., SIL International, Dallas, TX.

Wendland, E.R., 2004, Translating the literature of Scripture: A literary-rhetorical approach to Bible translation, SIL International, Dallas, TX.

Wendland, E.R., 2011, Life-style translating: A workbook for Bible translators, 2nd edn., SIL International, Dallas, TX.

Whybray, N., 1996, Reading the Psalms as a book, Sheffield Academic Press, Sheffield, UK.

Wilt, T. \& Wendland, E., 2008, Scripture frames \& framing: A workbook for Bible translators, SUN Press, Stellenbosch, RSA. 